\title{
Emotional Mental Problems among Adolescents: Urban and Semi- Urban Settings
}

\author{
Meita Dhamayanti, ${ }^{1}$ Stanza Uga Peryoga, ${ }^{1}$ Mohamad Rizqy Firmansyah ${ }^{2}$ \\ ${ }^{1}$ Department of Child Health Faculty of Medicine Universitas Padjadjaran/Dr. Hasan Sadikin \\ General Hospital Bandung, Indonesia, ${ }^{2}$ Faculty of Medicine Universitas Padjadjaran, Indonesia
}

\begin{abstract}
Background: Emotional mental problems refer to something that complicates someone in an attempt to conform to the environment and experiences. In Indonesia the prevalence of emotional mental problems is $6.0 \%$. In West Java province as the most populous region in Indonesia, the number of prevalence is above the national average of $9.3 \%$. West Java province was selected for this study because in addition to being the most densely populated region, it also has urban and semi-urban areas. The purpose of this study was to identify the difference in the prevalence of emotional mental problems of adolescent in urban and semiurban areas.

Methods: This study used the cross sectional approach method. Inclusion criteria were adolescents aged 14-16 years who attended several Junior High and Senior High Schools in Cirebon City as an urban area and Sumedang Regency as a semi-urban area. Exclusion criteria were adolescents who filled out the questionnaire incompletely. The study variables consisted of adolescents, urban and semi-urban areas, and emotional mental problems. Data were analyzed by using chi square $\left(\mathrm{x}^{2}\right)$ test.

Results: Out of 1039 respondents, 816 met the inclusion criteria. There were significant differences in emotional mental problems on the aspects of emotional symptoms, behavior, hyperactivity, interpersonal relationships, social behavior, and total value of emotional mental problems with p value $<0.05$.

Conclusions: There is a difference in emotional mental problems of adolescents in urban and semi-urban areas. Adolescents in urban regions have higher mental-emotional problems than in semi-urban regions.
\end{abstract}

Keywords: Adolescents, urban, semi-urban, emotional mental problems

\section{Introduction}

Mental-emotional problem is a complicated factor in a person's ability to conform with his/her environment and experiences. Mentalemotional problems may arise if there are certain circumstances hampering someone's ability to conform with their environment and experiences. According to a study by the World Health Organization (WHO), as many as 104 of 1000 children aged 4-15 years old have mental-emotional problems. ${ }^{1,2}$ One of the factors influencing adolescent mentalemotional problems is the demographic status difference. ${ }^{3}$

Indonesia consists of several regions categorized as urban and semi-urban. In Indonesia, prevalence of mental-emotional problems is $6 \%$ and West Java province with the highest population density in Indonesia have an incidence rate above the national average as much as $9.3 \%{ }^{4}$ As the densest region with urban and semi-urban regions, West Java province is selected for this study, where the urban region is represented by Kota Cirebon, and semi-urban is represented by Kabupaten Sumedang. The aim of this study was to determine the differences in the prevalence of mental-emotional problems among adolescents in urban and semi-urban regions.

\section{Methods}

An observational analytic study with cross-sectional approach was carried out using secondary data from the Academic Leadership Grant (ALG) study at the Faculty of Medicine Universitas Padjadjaran Bandung. The inclusion criteria of this study were adolescents aged 14-16 years who were enrolled in several Junior High Schools and

Correspondence: Meita Dhamayanti, Department of Child Health, Faculty of Medicine, Universitas Padjadjaran/Dr. Hasan Sadikin General Hospital, Jalan Pasteur 38, Bandung, Indonesia, Email: meita.dh@gmail.com 
Senior High Schools in Kota Cirebon as the urban region and Kabupaten Sumedang as semi-urban region. The exclusion criteria were subjects who did not fill the questionnaire completely. The study variables consisted of adolescents, urban and semi-urban region, and mental-emotional problem.

The sample in this study was determined using simple randomized sampling. The sample size acquired with large sample formula for comparing two unpaired independent proportions. Out of 1039 subjects, only 816 subjects met the inclusion criteria. The dependent variable in this study was mentalemotional problems in adolescents and independent variables were adolescents in urban and semi-urban regions. Data collection and analysis was conducted from March to May 2017.

Data were collected and analyzed after it was granted ethical exemption from the Health Research Ethics Committee Faculty of Medicine, Universitas Padjadjaran No: 384/ UN6.C.10/PN/2017. Furthermore, the dataata were analyzed using the univariate and bivariate method. The univariate analysis is characteristics for scoring of mental-emotional problems in respondents presented in tables. The bivariate analysis was performed in the form of a differential test between two studied groups using chi square $\left(\mathrm{x}^{2}\right)$. However, if there were cells with expected count value $<5$, then the alternative test from chi square was used instead, which was the Fischer test ( $2 \times 2$ table) or Kolmogorov-Smirnov test (2xk table). The difference was considered significant if $\mathrm{p}$-value $<0.05$.

\section{Results}

This study discovered that regarding gender, from 816 subjects there were more males in the urban than in semi-urban areas. Regarding ethnicity, in the urban area, there were various ethnic groups compared to the semi- urban area. In the urban area, the mother's and father's education level of the subjects was higher compared to those in the semi-urban area (Table 1).

Moreover, there were significant differences between urban and semi-urban regions in emotional symptom, behavior problem, hyperactivity level, peer to peer (interpersonal) relationships, social behavior, and mental-emotional problems with p-value $<0.05$ (Figure 1).

\section{Discussion}

Based on the acquired data, the emotion level of adolescents in the urban region were higher than those in semi-urban region. This finding matches the theory by Lazarus in Saputra et $a .^{5}$ that states urban regions have higher population density and may cause more stress to its residents. This stressor may induce intense emotional reaction, anger, criminality,

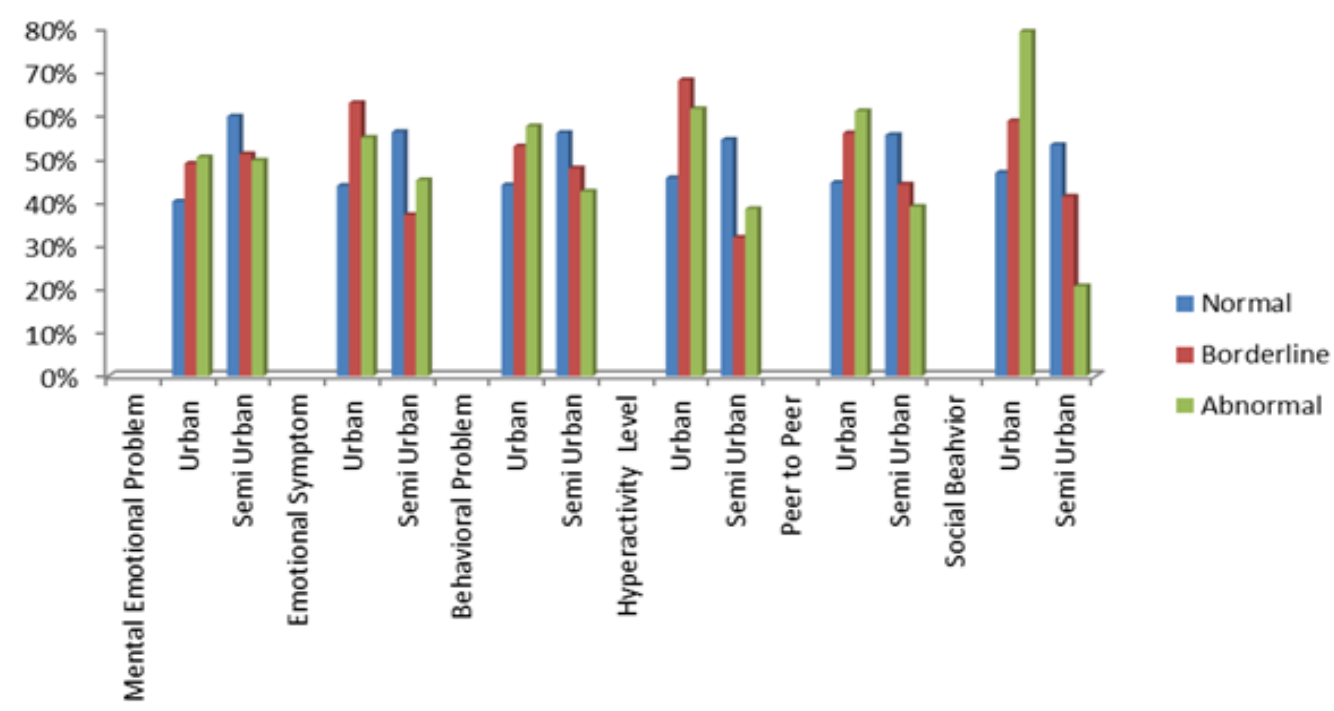

Figure 1 Difference in Prevalence of Mental-Emotional Problems Among Adolescent in Urban and Semi-Urban Regions 
Table 1 General Characteristic of Subjects

\begin{tabular}{|c|c|c|c|}
\hline General Characteristics & Urban $(n=399)$ & Semi Urban $(n=417)$ & $P=$ Value \\
\hline \multicolumn{4}{|l|}{ Gender } \\
\hline Male & $184(55.8 \%)$ & $146(44.2 \%)$ & 0.001 \\
\hline Female & $215(44.2 \%)$ & $271(55.8 \%)$ & \\
\hline \multicolumn{4}{|l|}{ Education level } \\
\hline Junior High School & $218(50.3 \%)$ & $215(49.7 \%)$ & 0.379 \\
\hline Senior High School & $181(47.3 \%)$ & $202(52.7 \%)$ & \\
\hline \multicolumn{4}{|l|}{ Ethnicity } \\
\hline Melayu/Minang & $11(73.3 \%)$ & $4(26.7 \%)$ & 0.000 \\
\hline Batak & $12(57.1 \%)$ & $9(42.9 \%)$ & \\
\hline Sundanese & $96(19.8 \%)$ & $388(80.2 \%)$ & \\
\hline Javanese & $269(95.1 \%)$ & $14(4.9 \%)$ & \\
\hline Batavia & $0(0 \%)$ & $1(100 \%)$ & \\
\hline Balinese & $1(100 \%)$ & $0(0 \%)$ & \\
\hline Makassar & $0(0 \%)$ & $1(100 \%)$ & \\
\hline Madura & $1(100 \%)$ & $0(0 \%)$ & \\
\hline Others & $9(100 \%)$ & $0(0 \%)$ & \\
\hline \multicolumn{4}{|l|}{ Religion } \\
\hline Islam & $389(48,7 \%)$ & $410(51.3 \%)$ & 0.525 \\
\hline Christian & $7(53.8 \%)$ & $6(46.2 \%)$ & \\
\hline Catholic & $1(50.0 \%)$ & $1(50.0 \%)$ & \\
\hline Buddhist & $2(100,0 \%)$ & $0(0,0 \%)$ & \\
\hline \multicolumn{4}{|l|}{ Mother's Education Level } \\
\hline Not schooled & $13(92.9 \%)$ & $1(7.1 \%)$ & 0.000 \\
\hline Elementary & $97(55.7 \%)$ & $77(44.3 \%)$ & \\
\hline Junior High School & $48(45.7 \%)$ & $57(54.3 \%)$ & \\
\hline Senior High School & $132(44.7 \%)$ & $163(55.3 \%)$ & \\
\hline Diploma & $15(51.7 \%)$ & $14(48.3 \%)$ & \\
\hline Bachelor's degree & $38(35.5 \%)$ & $69(64.5 \%)$ & \\
\hline Postgraduate degrees & $8(66.7 \%)$ & $4(33.3 \%)$ & \\
\hline Do not know & $48(60.0 \%)$ & $32(40.0 \%)$ & \\
\hline \multicolumn{4}{|l|}{ Father's Education Level } \\
\hline Not schooled & $8(88.9 \%)$ & $1(11.1 \%)$ & 0.001 \\
\hline Elementary & 74(49.7\%) & $75(50.3 \%)$ & \\
\hline Junior High School & $45(52.9 \%)$ & $40(47.1 \%)$ & \\
\hline Senior High School & $136(47.4 \%)$ & $151(52.6 \%)$ & \\
\hline Diploma & $18(52.9 \%)$ & $16(63.4 \%)$ & \\
\hline Bachelor's degree & $48(36.6 \%)$ & $83(63.4 \%)$ & \\
\hline Postgraduate degree & $7(31.8 \%)$ & $15(68.2 \%)$ & \\
\hline Do not know & $63(63.6 \%)$ & $36(36.4 \%)$ & \\
\hline
\end{tabular}


and juvenile delinquency. Meanwhile, semiurban regions have lower population density thus give off more peaceful surroundings that the residents are less likely to be emotional. ${ }^{5}$ Furthermore, urban regions with competitive surroundings and higher expectations to life can provoke conflict and anger. ${ }^{6}$ On the other hand, semi- urban regions with their mutualism and upholding traditional cultures influence their adolescence to be more sensitive to people around them and stabilize their emotions. ${ }^{7}$

Based on acquired data, behavioral problems among adolescence in the urban region were higher than in semi-urban region. This is in line with a theory by Gonzales et al. ${ }^{8}$ that there are factors influencing behavior in adolescence, such as environment (family, friends, teachers), state of surroundings (density), and individual (genetic and gender) that can influence adolescent behavior, importantly high risk behaviors. In this case, adolescence in urban regions receive more stimuli than those in semi-urban regions, for example in urban regions there are more vehicles and people, dense residence and business places, and movement area at home that are too tight causing adolescents in urban regions to be more likely to moan and complain, bored, wanting to flee from daily hustle, and others that can influence high risk factors in adolescents. ${ }^{9}$ While in semi- urban regions, there are less vehicles and people, more area to play and move thus intersection between one another are relatively small. 8,9

From acquired data, the hyperactivity level in adolescents in the urban area was higher than in semi-urban area. This finding aligns with a theory by Sobanski that factors playing a role in hyperactivity are family issues, socialeconomic status, large amount of family, parental factors including criminal parent and those with mental illness, and children raised in daycare. ${ }^{10}$

Moreover, from obtained data the level of problems among peers in the urban region were higher than in semi-urban. This is consistent with a theory by Brechwald and Prinstein ${ }^{11}$, where explosive emotional reactions can cause adolescents to be more likely to have issues with their peers. The presence of problems among peers could influence negative behavior in adolescents such as smoking, drug consumption, alcohol drinking, violence and criminality, and antisocial behaviors. This matches with a study indicating adolescents in semi-urban region are with higher emotional levels than those in semi-urban region which make those in urban region to have more problems among their peers. ${ }^{11}$

The summation of scores from emotional symptoms, behavioral problems, hyperactivity, and peer association become the value of the total score in adolescent mental-emotional problems. Mental-emotional problems among adolescents in urban region were higher than those in semi-urban region. This may be due to the characteristics in family environment, peers, and society and are relatively different. ${ }^{12}$ Mental-emotional problems may not only be caused by those factors, but also by the interaction of several factors such as genetic, environment, friends, and society. ${ }^{1,13,14}$

Additionally, based on acquired data, the normal social behavior value in the semiurban region is higher than the urban region, which means that those people have protective factors against mental-emotional problems. The social behavior value is equal in meaning with the protective factor, which is a factor that modifies, changes, or forms response of a person to become stronger facing challenges from their environments, and explains that not all adolescents who have risk factors will experience behavioral or emotional problems, neither certain mental problems. ${ }^{1,13,14}$

Meanwhile, social behavior included in the borderline and abnormal category were higher in urban than semi-urban region. The borderline and abnormal categories have weaker protective factors to mental-emotional problems, thus have higher risk to suffer from mental-emotional problems. ${ }^{1,13,14}$

Based on this study, it can be inferred that there are significant differences in mentalemotional problems among adolescents in urban regions and semi-urban regions, where urban regions have higher mental-emotional problems than semi urban regions. The limitation of this study is that it only includes one province, and will be more appropriate with more provinces. Furthermore, the characteristic components from respondents need to be added and Focused Group Discussions (FGD) should be conducted to discuss more about this study. This study suggests the need for a form of approach for students with a risk to experience mentalemotional problems, included are students in the borderline category, so it will not develop into mental-emotional problems, involving counseling teachers in schools and parents of corresponding students. Moreover, early detection is needed using the SDQ questionnaire every 6 months so students 
having risk factors for mental-emotional problems can be detected.

\section{References}

1. Damayanti M. Masalah mental emosional pada remaja: deteksi dan intervensi. Sari Pediatri. 2011;13(Suppl 1):45-51

2. Srinath S, Kandasamy P, Golhar TS. Epidemiology of child and adolescent mental health disorders in Asia. Curr Opin Psychiatry. 2010;23(4):330-6.

3. Departemen Kesehatan Republik Indonesia. Riset kesehatan dasar. Jakarta. Jakarta: Badan Penelitian dan Pengembangan Kesehatan Kementrian Kesehatan RI; 2013. p. 128-9.

4. Badan Pusat Statistik Provinsi Jawa Barat. Angka prevalensi masalah mental emosional pada remaja. Bandung; 2017 [cited 2017 February 4]; Available from: https://jabar.bps.go.id/linkTabelStatis/ view/id/93.

5. Saputra F, Yunibhand J, Sukratul S. Relationship between personal, maternal, and familial factors with mental health problems in school-aged children in Aceh province, Indonesia. Asian J Psychiatry. 2017;25(1):207-12.

6. Adrian M, Zeman J, Erdley C, Lisa L, Sim L. Emotional dysregulation and interpersonal difficulties as risk factors for nonsuicidal self-injury in adolescent girls. J Abnorm Child Psychol. 2011;39(3):389-400.

7. Wiguna T, Manengkei PSK, Pamela C, Rheza AM, Hapsari WA. Masalah emosi dan perilaku pada anak dan remaja di poliklinik jiwa anak dan remaja RSUPN dr. Ciptomangunkusumo (RSCM), Jakarta. Sari Pediatri. 2016;12(4):270-7.
8. Gonzales NA, Coxe S, Roosa MW, White $\mathrm{R}$, Knight GP, Zeiders KH, et al. Economic hardship, neighborhood context, and parenting: prospective effects on MexicanAmerican adolescent's mental health. Am J Community Psychol. 2011;47(1-2):98113.

9. Hunt J, Eisenberg D. Mental health problems and help-seeking behavior among college students. J Adolesc Health. 2010;46(1):3-10.

10. Sobanski E, Banaschewski T, Asherson P, Buitelaar J, Chen W, Franke B, et al. Emotional lability in children and adolescents with attention deficit/ hyperactivity disorder (ADHD): clinical correlates and familial prevalence. J Child Psychol Psychiatry. 2010;51(8):915-23.

11. Brechwald WA, Prinstein MJ. Beyond homophily: a decade of advances in understanding peer influence processes. J Res Adolesc. 2011;21(1):166-79.

12. Schonert-Reichl KA, Lawlor MS. The effects of a mindfulness-based education program on pre-and early adolescents' well-being and social and emotional competence. Mindfulness. 2010;1(3):137-51.

13. Mendes AV, Souza Crippa JA, Souza RM, Loureiro SR. Risk factors for mental health problems in school-age children from a community sample. Matern Child Health J. 2013;17(10):1825-34.

14. Aebi M, Giger J, Plattner B, Metzke CW, Steinhausen H-C. Problem coping skills, psychosocial adversities and mental health problems in children and adolescents as predictors of criminal outcomes in young adulthood. Eur Child Adolesc Psychiatry. 2014;23(5):283-93. 